\title{
Lęk akulturacyjny cudzoziemców w aspekcie tożsamości i procesów integracyjnych w nowym kraju pobytu
}

„Kiedy staramy się poznawać innych, aby sprostać wyzwaniom zwiazanym z różnorodnościq kulturowa, największe trudności napotykamy w nas samych".1.

\section{Wstęp}

bce kultury od zarania dziejów przenikały się nawzajem, wytyczając przemiany kulturowe wielu społeczeństw. Proces ten obecnie ma charakter globalny i niesłychanie dynamiczny. Kulturowe odmienności wywołują problem wzajemnego współistnienia i efektywnego porozumiewania się, a ich obecność na ograniczonym terytorium, w świetle ewentualnych zagrożeń i konfliktów, stanowi wyzwanie dla obu stron: dla rządu i obywateli danego państwa, jak również dla imigrantów. Ruch migracyjny z jednej strony aktywizuje rozwój w wielu dziedzinach, jednak z drugiej - wywołuje lęk i zachwianie poczucia bezpieczeństwa. Często wynika to z historycznych faktów, konfliktów międzygrupowych, zaistniałych w przeszłości oraz sposobów ich rozwiązywania, jednak w dużym stopniu wiąże się z aktualnym poziomem rozwoju świadomości zbiorowej, społecznej. Przyjęcie określonych strategii i metod, w celu regulowania stosunków międzygrupowych, zależne jest od poziomu świadomości kulturowej społeczeństwa, ale także od świadomości poszczególnych jego członków, ich zdolności do elastycznego myślenia $\mathrm{w}$ aspekcie wielokulturowości i osobistych kompetencji radzenia sobie z nią. Obie świadomości - jeds. 45 .

Cyt. za D. Matsumoto, L. Yuang, Psychologia międzykulturowa, Gdańsk 2007, 
nostkowa i zbiorowa - wzajemnie na siebie wpływają. Jest to złożony proces o mechanizmie sprzężenia zwrotnego, gdyż konflikty na płaszczyźnie międzykulturowej to głównie efekt ograniczeń osobistych przedstawicieli różnych kultur, wynikających z ich świadomości podmiotowej, a wzmacnianych przez świadomość zbiorową własnej grupy pochodzenia i odwrotnie. Procesy te dotyczą zarówno członków obcych kultur, jak i nas samych, i chociaż nie jest możliwe mieć nad nimi pełnej kontroli, należy docenić ich wagę.

Zróżnicowanie kulturowe populacji w wielu krajach wzrasta coraz bardziej, także w naszym. Współdziałanie i przenikanie się różnych grup kulturowych jest procesem nieuniknionym i jednocześnie długotrwałym. Stiepanowicz i Szasz wymieniają kilka poziomów wzajemnego oddziaływania kultur: etniczny, narodowościowy polityczny, ekonomiczny i cywilizacyjny $^{2}$, które stanowią przedmiot dociekań naukowych wielu badaczy. Jednakże w aspekcie procesów integracyjnych nadal niedoceniona wydaje się być płaszczyzna interpersonalna ${ }^{3}$, gdyż głównie dzięki bezpośrednim, osobistym spotkaniom przedstawicieli różnych kultur następuje przejmowanie i zespolenie elementów obcej kultury z własna, co w efekcie odciska swój ślad w procesie kształtowania tożsamości jednostki.

Przebieg procesu akulturacji cudzoziemców zdeterminowany jest zarówno czynnikami zewnętrznymi, jak i wewnętrznymi. Na kontekst zewnętrzny składa się wiele aspektów, m.in.: rola państwa, polityka na rzecz imigrantów, płaszczyzna ekonomiczna, społeczna. Mimo dużej ich wagi, jakość relacji międzykulturowych w niebagatelnym stopniu zależy od każdego uczestnika interakcji, jego potencjału wewnętrznego, indywidualnych kompetencji. To one kształtują percepcję i obraz świata oraz stosunek do obcej kultury. Samoświadomość ${ }^{4}$, czyli kontakt z własnym JA, może być u poszczególnych jednostek rozwinięty w różnym stopniu, a to przekłada się na jakość kompetencji komunikacyjnych i adaptacyjnych. Zależnie od stopnia ich rozwoju ów szeroko rozumiany potencjał wew-

2 W. A. Stiepanowicz, S. D. Szasz, Współdziałanie kultur w warunkach pogranicza. Ujęcie teoretyczne problemu, w: Bezpieczeństwo człowieka a wielokulturowość, red. J. Dębowski, E. Jarmoch, A. W. Świderski, Siedlce 2008, s. 132. Por.: B. Ociepka, Komunikowanie międzynarodowe, Wrocław 2002, s. 14.

3 Efektywność komunikacji międzykulturowej na płaszczyźnie indywidualnej, interpersonalnej i grupowej w aspekcie czynników psychologicznych przedstawiam szerzej w: M. Wallas, Dialog międzykulturowy-szanse i ograniczenia, w: Drogi i bezdroża komunikacji, red. P. Bering, G. Łukomski, Gniezno 2008, s. 260-265.

4 Pojęcie samoświadomości szerzej omawiam w: ibidem, s. 259. 
nętrzny może pomagać lub przeszkadzać w akulturacji, także wtedy, gdy migracja wnika z własnej, dobrowolnej decyzji cudzoziemca. Przystosowanie do nowej kultury wyzwala stres, lecz dla różnych osób oznacza inny stopień trudności. W procesie akulturacji wnętrze człowieka jako płaszczyzna indywidualna wytycza nie tylko rodzaj ekspresji zachowania i kierunek działania, ale też jakość i klimat interakcji z obcymi - zarówno na płaszczyźnie interpersonalnej, jak i grupowej.

Istotnym czynnikiem wewnętrznym dla integracji z obcą kulturą jest stopień identyfikacji z kulturą własną i odpowiednio ukształtowane w niej poczucie tożsamości. Wyznaczają one siłę etnocentryzmu oraz kierunek motywacji - do lub od - w aspekcie podejmowania kontaktów z obcymi. Negatywna motywacja może wzmagać poczucie stresu akulturacyjnego i wyzwalać całą gamę negatywnych emocji, prowadząc do niepowodzeń komunikacyjnych podczas realizacji celów, wywołując rozmaite konflikty, dotyczące politycznych interesów obcokrajowców w nowym kraju. Deficyt własnych kompetencji lub zaburzenia wewnętrzne także stanowią znaczące utrudnienie w rozwiązywaniu problemów akulturacyjnych. W zakresie czynników wewnętrznych poważną barierą w adaptacji do obcej kultury jest lęk - cecha, jako rys osobowości. Wśród wielu emocji, jakie przeżywa człowiek, lęk najbardziej ogranicza jego aktywność i kreatywność, również w obszarze integracji kulturowej. W przypadku negatywnych doświadczeń i przykrych emocji jednostka lękowa może nadmiernie wzmacniać w sobie barierę do otwartego dialogu międzykulturowego.

Ponadto kontaktom międzygrupowym często towarzyszy także lęk grupowy. Wzajemne indukowanie się lękiem we własnej grupie kulturowej to mechanizm, pogłębiający stan niepokoju jednostek, prowadzący do unikania kontaktów z obcymi ${ }^{5}$. Umacnia on dystans i wrogość, obniżając możliwości integracyjne jednostek i grup z innymi kulturami.

Natomiast potrzeba przynależności do nowej kultury, mimo doświadczania lęku, zachęca do podejmowania interakcji i budowania relacji długoterminowych z tuziemcami opartych na osobistej więzi. Nawiązywanie przyjaźni, zawieranie małżeństw dwukulturowych sprzyja zmianie wewnętrznej cudzoziemców oraz integracji i pomaga zakorzenić się w nowym środowisku, co potwierdza przeprowadzone przeze mnie badanie pilotażowe $(2009)^{6}$.

5 Ibidem, s 263.

6 M. Wallas, Znaczenie indywidualnych czynników w procesie akulturacji cudzoziemców. Raport z badań pilotażowych, artykuł oddany do druku 2009. 


\section{Lęk akulturacyjny}

Przystosowanie się człowieka do nowego środowiska kulturowego uruchamia emocjonalne aspekty jego reakcji. Niepowodzeniom towarzyszą emocje negatywne, które informują o konieczności zwiększenia wysiłku w celu poprawy skuteczności działania. Z kolei emocje pozytywne pojawiają się, gdy osoba osiągnęła stan wyższy niż optymalny, a doświadczanie przyjemności jest sygnałem domknięcia określonej sprawy, co pozwala jej przekierować energię na nową, kolejną aktywność ${ }^{7}$. Jakkolwiek emocje pozytywne stanowią siłę napędową do dalszego działania i rozwoju, to emocje negatywne - w szczególności lęk - mogą demotywować i wyzwalać wycofanie lub agresję.

W sytuacji zagrożenia bezpieczniej czujemy się wśród swoich i tam szukamy schronienia. Lęk obniża aktywność behawioralną ${ }^{8}$, natomiast wzmaga ją na poziomie umysłowym, w postaci negatywnych wyobrażeń dotyczących kontaktów z obcymi ${ }^{9}$, które nie muszą znajdować potwierdzenia w realiach. Zależność między lękiem a wyobrażeniami ma charakter dodatniego sprzężenia zwrotnego - im bardziej się boimy, tym bardziej wyobrażamy sobie negatywne konsekwencje; im więcej negatywnych wyobrażeń konstruuje umysł, tym bardziej się boimy. Lęk to emocja, która ogranicza, obezwładnia i nie zachęca do kontaktu, stanowi barierę trudną do przekroczenia, utrudniając kontakt międzykulturowy.

Lęk, wg Kępińskiego, działa na funkcjonowanie człowieka dwojako. Podobnie jak ból jest biologicznie potrzebny. Niski jego poziom działa na psychikę integrująco, a wysoki - dezintegrująco. W pozytywnym znaczeniu lęk ułatwia formowanie się systemu hierarchii wartości ${ }^{10}$, na którym opierają się podejmowane decyzje, cele i działania. Z kolei człowiek żyjący w silnym lęku, czuje się zagubiony i przeżywa chroniczny stres, ponieważ postrzega świat jako zagrożenie i silniej reaguje emocjami negatywnymi. Na obczyźnie, gdzie brak bezpośredniego wsparcia bliskich, lęk może dawać o sobie znać szczególnie mocno.

Spielberger rozróżnia dwa znaczenia pojęcia lęku: lęk jako stan, odczuwany w konkretnej sytuacji oraz lęk jako cecha osobowości, tzn. cha-

7 W. Bąk, P. Oleś, Lęk w kontekście procesów samoregulacji, w: Lęk, geneza, mechanizmy, funkcje, red. M. Fajkowska, B. Szymura, Warszawa 2009, s. 239.

8 M. Wallas, Dialog międzykulturowy..., op. cit., s. 260.

9 W. G. Stephan, C. W. Stephan, Wywieranie wptywu przez grupy. Psychologia relacji, Gdańsk 2002, s. 136.

10 A. Kępiński, Lęk, Warszawa 1987, s. 304-305. 
rakterystyczny rys jednostki, nabyty w okresie wczesnego dzieciństwa i utrzymujący się $\mathrm{w}$ trakcie jej życia na względnie stałym poziomie ${ }^{11}$. W przypadku lęku-cechy autor określa go jako wyuczoną dyspozycję ${ }^{12}$. Lęk-cecha jest niejako wpisany w JA człowieka. Wynika z porównywania siebie i swoich zachowań do różnych standardów i wartości, wpływając na sposób oraz kierunek działania. Gdy człowiek stwierdza rozbieżność między własnym JA i ważnym dla siebie standardem, w oparciu o posiadane indywidualne predyspozycje ${ }^{13}$, może wybrać wycofanie jako działanie ucieczkowe albo dokonać zmiany zachowania.

Wrześniewski i Włodarczyk w swych najnowszych badaniach nad lękiem wykazują ponadto, że wewnętrzne dyspozycje mogą wpływać na sposób sytuacyjnej oceny stresu, wywołując u jednostki określony stan emocjonalny. Oznacza to, że osoby z wysokim lękiem-cechą mogą doświadczać $\mathrm{w}$ określonej sytuacji wyższy poziom lęku-stanu ${ }^{14}$.

Wobec powyższego lęk akulturacyjny to dyspozycja człowieka, nabyta w okresie wczesnego dzieciństwa wskutek procesu socjalizacji we własnej kulturze, która, utrzymując się w czasie całego życia na względnie stałym poziomie, ulega wzmocnieniu w sytuacjach obcych kulturowo, subiektywnie postrzeganych i interpretowanych przez jednostkę jako zagrożenie, co dodatkowo powoduje silniejsze doświadczanie stresu, wyzwalając lęk jako stan oraz specyficzny rodzaj działań zaradczych, które mogą implikować określoną ich efektywność i formę osiągniętej asymilacji kulturowej ${ }^{15}$.

Wnioski z własnego badania pilotażowego, dotyczące lęku, pokazują, że cudzoziemcy we wszystkich fazach pobytu ${ }^{16}$, mimo zróżnicowanego klimatu emocjonalnego, doświadczają dość stały poziom lęku, który - choć nieco spada w ostatniej - utrzymuje się przez cały czas. Emocje lękowe, bez względu na płeć, zgłasza ponad połowa grupy. Ową niezmienną

11 C. D. Spielberger, Theory and research on anxiety, w: Anxiety and Behavior, C. D. Spielberger, New York 1966, s. 17.

12 Test Inwentarz Stanu i Cechy Lęku STAI, Podręcznik, Pracownia Testów Psychologicznych, Warszawa 1987, s. 4.

13 W. Bąk, P. Oleś, op. cit., s. 231-234.

14 K. Wrześniewski, D. Włodarczyk, Lęk jako cecha a ocena stresu i stan emocjonalny u osób po zawale serca, w: Lęk, geneza, mechanizmy, funkcje, red. M. Fajkowska, B. Szymura, Warszawa 2009, s. 439.

15 Tu: Definicja lęku akulturacyjnego została rozszerzona - por. artykuł w druku; ponadto poszczególne formy asymilacji również omawiam: ibidem.

16 Kolejne fazy pobytu w trakcie procesu akulturacji - szerzej w: ibidem. 
stałość doświadczania lęku we wszystkich fazach deklaruje ponad 1/3 badanych, szczególnie osoby w dojrzałym wieku i długiego pobytu. Większość grupy L+ (3/4 osób) wprost nazywa swe stany lękowe jako barierę w adaptacji. Grupa L+ odczuwa stres akulturacyjny silniej i uzyskuje niższe, od L-, wyniki akulturacji. Badani L+ potrzebują też więcej czasu, by osiaggnąć stabilizację akulturacyjną. Ponadto emocje lękowe częściej zgłaszają badani spoza Europy. Rys lękowy, utrzymujący się w kolejnych fazach pobytu u tych samych osób, wyraźnie podkreśla znaczenie lęku-cechy w procesie akulturacji ${ }^{17}$.

Kontaktom międzygrupowym towarzyszy również lęk grupowy (międzygrupowy), rozumiany jako zgeneralizowana reakcja emocjonalna, doświadczana przez daną grupę kulturową w stosunku do grupy obcej. Do jego przyczyn można zaliczyć: słaby kontakt z obcą kulturą oraz konflikty z nią w przeszłości, różnice statusu między grupami, niski stan wiedzy o grupie obcej, wysoki poziom uprzedzeń i wysoki poziom etnocentryz$\mathrm{mu}^{18}$. Stan niepokoju w grupie często pogłębia fakt wzajemnego indukowania się lękiem, co zwiększa dystans wobec obcych i prowadzi do unikania z nimi kontaktów. Przesłanki potwierdzające ten wniosek pojawiają się $\mathrm{w}$ przeprowadzonym przeze mnie eksperymencie - w trakcie realizacji warsztatów z grupami AAL (2006) ${ }^{19}$. Uczestnicy spontanicznie dokonali podziału: na grupę wielokulturową i monokulturową, chociaż zaplanowano pracę w dwóch grupach zróżnicowanych kulturowo. To zaskakujące zdarzenie pozwoliło uzyskać wiele ciekawych obserwacji i wniosków. Poszukując wyjaśnienia zaistniałego faktu podziału, zaryzykowałam hipotezę, że w grupie monokulturowej u podłoża takiej motywacji wyboru mógł tkwić lęk przed ludźmi z obcej kultury. Niepokój ten, pociagając za sobą konsekwencje w sferze poznawczej, afektywnej i behawioralnej, znajduje wyraz w uzyskanych obserwacjach, dotyczących zarówno procesu dynamiki grupowej, jak i wydajności zadaniowej obu grup. Grupa monokulturowa była zdecydowanie mniej efektywna zadaniowo. Zamiast

17 Oznaczenia L+ i L- dotyczą odpowiednio grupy „lękowej” i grupy „bez lęku”. Szczegółowa analiza wyników badań i wnioski omówione zostały w raporcie z badań pilotażowych: ibidem.

18 W. G. Stephan, C. W. Stephan, op. cit., s. 137.

19 Eksperyment naturalny uczestniczący - przeprowadzony w dwóch grupach AAL w trakcie warsztatów na temat: Pokonywanie stereotypów i uprzedzeń międzykulturowych - wraz z uzyskanymi wnioskami został szeroko opisany w: Dialog międzykulturowy..., red. M. Wallas, op. cit., s 265-270. 
na zadaniu skupiała swą uwagę na potrzebie zachowania spójności i solidarności, co dawało jej poczucie bezpieczeństwa; a w procesie dynamiki grupowej osiagnęła tylko drugą fazę rozwoju - oporu ${ }^{20}$. Natomiast grupa wielokulturowa, mimo zróżnicowanego narodowościowo składu, na poziomie behawioralnym nie wykazywała lęku. W atmosferze wspólnej, radosnej zabawy edukacyjnej, w klimacie pełnej wzajemnej tolerancji i akceptacji, osiagnęła wysoki poziom integracji (faza konsolidacji) oraz lepsze efekty zadaniowe. Ponadto, doświadczane na bieżąco różnice kulturowe także potraktowała zadaniowo. Mimo tych różnic i dzięki uwzględnianiu wzajemnych potrzeb, grupa wielokulturowa osiagnęła sukces integracyjny.

\section{Stres akulturacyjny i jego pozytywne aspekty}

W sytuacji zmiany miejsca pobytu, pojawia się problem stresu akulturacyjnego. Wywołują go zarówno czynniki zewnętrzne, związane z ogólnie pojmowanymi realiami nowego kraju pobytu: począwszy od klimatu i sposobu żywienia po jego politykę, jak również czynniki wynikające z wnętrza samej jednostki, np.: lęk, wrogie nastawienie do nowej kultury oraz rodzaj i jakość posiadanych przez nią kompetencji osobistych.

Sytuacje trudne kulturowo można potraktować jako sytuacje problemowe, jako nowe zadania, które pojawiają się w relacjach między reprezentantem kultury pochodzenia a przedstawicielami nowego kraju pobytu i przejawiają się ,...brakiem równowagi między obiektywnie istniejącymi wymaganiami a możliwościami jednostki..."21, wywołując dyskomfort i cierpienie lub mobilizując do działania w poszukiwaniu efektywnych rozwiązań. Osoba, oceniając sytuację jako stresową w obcym kulturowo

20 Tu: fazy rozwoju dynamiki grupowej w szerszym, niż psychoterapia, odniesieniu. Por.: Podstawy terapii grupowej, red. H. S. Bernard, K. R. MacKenzie, Gdańsk 2003, s. 46-67; M. S. Corey, G. Corey, Grupy. Zasady i techniki grupowej pomocy psychologicznej, Instytut Psychologii Zdrowia PTP, Warszawa 1995; L. Grzesiuk, Psychoterapia. Szkoty, zjawiska, techniki i specyficzne problemy, Warszawa 1995, s. 233-241; M. Armstrong, Zarzadzanie zasobami ludzkimi. Strategia i działanie, Kraków 1996, s. 142.

21 P. Szczepaniak, J. Strelau, K. Wrześniewski, Diagnoza stylów radzenia sobie ze stresem za pomoca polskiej wersji kwestionariusza CISS Endlera i Parkera, „Przegląd Psychologiczny" 1996, t. 39, nr 1, s. 188. 
środowisku, dokonuje jej klasyfikacji w zakresie kategorii: zagrożenia, wyzwania lub krzywdy/straty ${ }^{22}$.

Badania, przeprowadzone na uchodźcach i dobrowolnych emigran$\operatorname{tach}^{23}$, na które powołują się Matsumoto i Yuang, pokazują, że czynniki postemigracyjne takie, jak: utrata bliskiego otoczenia społecznego, izolacja społeczna, zaniechanie ważnych przedsięwzięć zawodowych (np. prowadzenie własnej firmy), utrata dotychczasowych ról społecznych i zawodowych oraz innych ważnych aktywności życiowych przyczynia się do pourazowych reakcji stresowych oraz cierpienia emocjonalnego i fizycznego w stopniu równym, a może nawet większym, jak u osób zmuszonych do ucieczki z kraju ojczystego z powodu przemocy politycznej, co potwierdzają także respondenci cytowanego badania pilotażowego. Wymienione czynniki to przykłady stresorów akulturacyjnych, wywołujących stan napięcia wewnętrznego, które mogą być odbierane przez emigrantów jako zagrażające. Są to sytuacje wymuszające przystosowanie się do zmiany, jaka zaszła w ich życiu.

Jakość osiagnniętej zmiany zależy od kompetencji adaptacyjnych cudzoziemca, który radzi sobie ze stresem akulturacyjnym lepiej lub gorzej. Dana osoba może wykorzystać tylko ten potencjał, który posiada, czyli cechy osobowości, system wartości, kompetencje w obszarze zawodowym i społecznym, dotychczasowe doświadczenie oraz własną zdolność uczenia się. Jednakże, zanim nauczy się nowych strategii działania, często uruchamia te, które zna, czyli wyuczony i charakterystyczny dla siebie repertuar, niekoniecznie efektywny.

Akulturacja jest procesem trudnym, wywołującym wiele napięć, wymagającym uwagi i zaangażowania. $\mathrm{W}$ początkowym okresie stanowi duże obciążenie dla organizmu, może nadwerężać jego układ nerwowy i odpornościowy, gdyż życie w obcej przestrzeni łączy się z koniecznością zrozumienia i akceptacji nowych realiów oraz zmiany nawyków. Osoba musi nauczyć się rozpoznawać i reagować na wiele nowych bodźców, które jej umysł dopiero uczy się selekcjonować ${ }^{24}$ i rozumieć. Proces ten szczególnie mocno daje o sobie znać w drugiej fazie pobytu

22 K. Wrześniewski, D. Włodarczyk, op. cit., s. 435.

23 D. Matsumoto, L. Yuang, op. cit., s. 440.

24 K. Pawlik, Skomunikować się. Rozważania w kontekście filmu Anna i król (reż. Andy Tennant), niepublikowana praca zaliczeniowa w ramach Akademii Artes Liberales, 2006, s. 4. 
w postaci szoku kulturowego oraz różnego rodzaju niedomagań fizycznych $^{25}$.

Wobec powyższego stres akulturacyjny to doświadczanie przez cudzoziemca trudności na styku własnej i obcej kultury, w postaci wewnętrznego napięcia i dyskomfortu, wynikającego z dysproporcji między wymaganiami nowej sytuacji kulturowej a jego kompetencjami adaptacyjnymi oraz wskutek subiektywnego postrzegania nowych sytuacji kulturowych jako trudnych, interpretowanych w kategorii: zagrożenia, wyzwania, straty i/lub krzywdy, którym nierzadko towarzyszą objawy w postaci dolegliwości fizycznych.

Ocena stresu może zależeć od aktualnych cech konkretnego zdarzenia albo od indywidualnych skłonności osoby, związanych np. z lękiem jako cechą. Przy tym właściwości dyspozycyjne mogą wpływać na sytuacyjną ocenę stresu i stan emocjonalny ${ }^{26}$. Zatem określona sytuacja trudna kulturowo może wyzwolić u obcokrajowca wzrost lęku-stanu, wzmocniony lękiem-cechą jako dyspozycją wewnętrzną, co w efekcie zwiększy siłę doświadczanego stresu oraz uaktywni charakterystyczny dla jednostki styl funkcjonowania. Koresponduje to z niezależnymi wnioskami z własnego badania, gdzie wykazano współwystępowanie u cudzoziemców podwyższonego poziomu lęku-cechy i stresu akulturacyjnego oraz różnego rodzaju trudności o charakterze emocjonalnym i społecznym. Uruchomienie wyuczonych przez osobę strategii działania w konsekwencji wpływa na przebieg i uzyskany poziom akulturacji ${ }^{27}$.

Osobowościowe wyznaczniki radzenia sobie ze stresem, implikują odmienne jakościowo rodzaje aktywności, w zakresie których jednostki wykazują określone preferencje. Względna ich stałość w zachowaniu pokazuje tendencję do stosowania określonego stylu ${ }^{28}$. Chociaż każda osoba posiada swój specyficzny styl zaradczy, należy również wziąć pod uwagę taką właściwość jak elastyczność w radzeniu sobie ze stresem ${ }^{29}$, która różnicuje ludzi w skuteczności ich działania. Lęk-cecha może stanowić jej ograniczenie. Przypuszczalnie osoby o podwyższonym poziomie lę-

25 Por.: G. Hofstede, Kultury i organizacje, Warszawa 2000, s. 304-306; M. Wallas, artykuł w druku.

26 K. Wrześniewski, D. Włodarczyk, op. cit., s. 435-438.

27 Uzyskano próg istotności, przyjęty dla małych prób (za J. Brzezińskim, Elementy metodologii badań psychologicznych, Warszawa 1978, s. 153).

28 I. Heszen-Niejodek, Teoria stresu psychologicznego i radzenia sobie, w: Psychologia. Podręcznik akademicki, red. J. Strelau, t. 3, Gdańsk 2007, s. 484-485.

29 Ibidem, s. 485. 
ku-cechy będą reagować w sposób mniej zróżnicowany i mało elastyczny. $\mathrm{Z}$ uwagi na podwyższony jego poziom mogą daną sytuację postrzegać jako zagrażającą bardziej, niż to konieczne oraz silniej reagować emocjonalnie albo, żeby nie odczuwać dyskomfortu, unikać sytuacji trudnych kulturowo.

Stres akulturacyjny, zależny od subiektywnej oceny sytuacji, w większości przypadków mobilizuje cudzoziemców do podjęcia jakiegokolwiek wysiłku w celu poradzenia sobie w nowych warunkach, tzn. odzyskania równowagi między wymaganiami otoczenia a własnymi możliwościami i poprawy stanu emocjonalnego ${ }^{30}$. W podejściu zadaniowym osoba traktuje stresor jak wyzwanie, dąży do poszukiwania informacji i rozwiązań, co wyzwala motywację w kierunku zbliżenia się do napotkanej trudności i chęci zmierzenia się z nią w sposób konstruktywny, a to wydaje się możliwe przy względnie niskim poziomie lęku-cechy. Natomiast osoba owładnięta lękiem spostrzega stresor jako zagrożenie i bezpośrednia z nim konfrontacja może być dla niej zbyt trudna. Toteż użyje innych, znanych sobie i nawykowo utrwalonych strategii, nie zawsze efektywnych, które zwykle nie prowadzą do rozwiązania sprawy, tylko ją odsuwają w czasie i/lub przestrzeni. Obniża to na pewien czas napięcie jednostki i daje poczucie ulgi, lecz problem pozostaje nadal nierozwiązany.

$\mathrm{Z}$ badania pilotażowego wynika, że sposoby poradzenia sobie ze stresem akulturacyjnym mogą zależeć od poziomu doświadczanego lęku. Osoby lękowe w aspekcie stylów radzenia sobie ze stresem wykazały tendencję do stosowania najmniej skutecznego - stylu skoncentrowanego na emocjach (SSE). Jednak w ich sposobie funkcjonowania uwidoczniła się również skłonność do poszukiwania wsparcia za pomocą kontaktów towarzyskich (PKT), a także - choć w nieco mniejszym stopniu - do angażowania się w czynności zastępcze (ACZ) jako sposobów łagodzenia napięć związanych ze stresem ${ }^{31}$.

Doświadczanie stresu wywołuje zwykle dyskomfort i cierpienie. Mimo to implikuje skutki o dwojakim charakterze: negatywne lub pozytywne, mobilizując tym samym do aktywności w różnych kierunkach. Negatywny aspekt stresu akulturacyjnego może zwiększać dystans, izolację i wrogość, demotywując do integracji i współdziałania z przedstawicielami obcej kultury albo prowadzić do utraty kontroli nad zachowaniem i wyzwalać agresję w stosunku do obywateli i państwa nowego pobytu.

30 Ibidem, s. 491.

31 Zastosowano oznaczenia stylów radzenia sobie za Endlerem i Parkerem w: P. Szczepaniak, J. Strelau, K. Wrześniewski, op. cit., s. 188-189. 
Natomiast pozytywne skutki stresu akulturacyjnego stanowią okazję do zdobycia nowych umiejętności, otwierając perspektywę dalszego rozwoju osobistych kompetencji. Jest to możliwe dzięki wysokiej samoświadomości jednostki, albowiem wykorzystując efektywnie pozytywne aspekty stresu, może ona:

- dokonać autoanalizy i dobrego rozeznania w sytuacji;

- odnaleźć dystans do stresora;

- odszukać wsparcie zarówno w sobie, jak i na zewnątrz - relacje długoterminowe (małżeństwa dwukulturowe, przyjaciele);

- odwołać się do skutecznych doświadczeń z przeszłości oraz nabywać nowe;

- poszukiwać konstruktywnych rozwiązań;

- rozróżniać swoje możliwości i ograniczenia w oparciu o adekwatny i realny obraz samego siebie (podejmowanie spraw, którym cudzoziemiec jest w stanie sprostać);

- przyjąć osobistą odpowiedzialność za to, co osoba może zrobić dla siebie w danej sytuacji trudnej kulturowo;

- konstruktywnie korzystać z opinii otoczenia;

- odnaleźć dystans do sytuacji i samego siebie w postaci poczucia humoru;

- zadbać o pozytywne nastawienie i optymizm w nowych realiach - wiara w powodzenie.

Respondenci badania pilotażowego podkreślali, że doświadczanie stresu akulturacyjnego skłoniło ich do wypracowania nowych strategii radzenia na przyszłość.

Jako przykład pozytywnych skutków stresu akulturacyjnego i sposobu poradzenia sobie $\mathrm{z}$ nim, w cytowanym badaniu pojawił się zgoła nowy fakt. Jest nim dokonanie zmiany wewnętrznej w systemie wartości osób lękowych. Otóż cudzoziemcy, którzy założyli w Polsce rodzinę dwukulturową, mimo podwyższonego poziomu stresu i lęku, osiagają lepszy poziom akulturacji (PA) niż badani stanu wolnego. Chociaż PA w grupie L+ ogólnie jest niższy niż w L-, to jednak lepszą akulturację osiagają osoby lękowe, żyjące w Polsce z bliskimi, aniżeli osoby L+ i L-, pozostające w stanie wolnym. Można przypuszczać, iż konieczność przystosowania się do partnera i rodziny z nowej kultury stawia z jednej strony wyższe wymagania, wywołując większy stres, lecz z drugiej - pomaga uzyskać wsparcie i bardziej sprzyja adaptacji, dając w efekcie wyższy poziom akulturacji. Właśnie w przypadku tej podgrupy uzyskanie wyższego poziomu akulturacji wiąże się z potrzebą dokonania zmiany wewnętrznej, co deklarują osoby L+ w zastosowanej ankiecie. Wniosek ten przemawia na 
korzyść posiadania bliskich w nowym kraju pobytu. Ponadto osoby lękowe, dokonujące zmiany, uzyskują o wiele wyższy poziom akulturacji, niż badani świadomi swych barier, którzy zdecydowanie deklarują brak potrzeby zmiany wewnętrznej.

Dokonanie zmiany wymaga wysokiej samoświadomości, zaangażowania i wysiłku oraz elastyczności w rozwiązywaniu trudności międzykulturowych, co w efekcie pozwala osiagnacć dobry poziom akulturacji ${ }^{32}$. Traktując fakt dokonania zmiany wewnętrznej jako specyficzny sposób poradzenia sobie ze stresem akulturacyjnym, który nie zawiera się $\mathrm{w}$ istniejących klasyfikacjach stylów zaradczych, koresponduje on z tezą Heszen-Niejodek o znaczeniu indywidualnych strategii radzenia jako ważnego warunku efektywności w stresie ${ }^{33}$.

Zależnie od poziomu samoświadomości i posiadanych kompetencji cudzoziemiec może opanować stres akulturacyjny w różnym stopniu:

1) brak możliwości poradzenia sobie, co w efekcie wywołuje poczucie braku kontroli i bezsilność, prowadząc do wycofania lub agresji, a w ekstremalnych przypadkach do zaburzeń psychicznych, nawet samobójstw;

2) nawykowe, automatyczne (nierefleksyjne) uruchamianie znanych sobie strategii na bazie posiadanych doświadczeń, często nieefektywnych w nowych realiach;

3) włączanie do posiadanych doświadczeń nowych strategii, które przypadkowo okazały się skuteczne w procesie adaptacji;

4) kreatywne i świadome, oparte na elastyczności, poszukiwanie nowych rozwiązań, niezależnie od wcześniej wypracowanych strategii własnych i cudzych, prowadzące w efekcie do zmiany wewnętrznej w osobistym systemie wartości.

Człowiek, jako istota twórcza, dzięki chęci pokonania barier wewnętrznych i dokonaniu ważnych przewartościowań, może rozwijać sposoby zaradcze i świadomie wpływać na swą efektywność akulturacyjną. Ponadto świadomość zaangażowania w proces akulturacyjny i satysfakcja z włożonego weń wysiłku stanowi pozytywne wzmocnienie emocjonalne dla JA, a także potwierdzenie znaczenia pozytywnych aspektów stresu akulturacyjnego. Proces ten nie może pozostać obojętny dla dalszego rozwoju tożsamości kulturowej cudzoziemca.

32 Wniosek ten nie potwierdza braku elastyczności osób lękowych w radzeniu sobie ze stresem. Aczkolwiek z powodu małej grupy badawczej należy potraktować go ostrożnie, gdyż wymaga dalszej weryfikacji.

33 I. Heszen-Niejodek, op. cit., s. 490. 


\section{Tożsamość i różne jej aspekty}

Tożsamość człowieka jest zjawiskiem złożonym i nastręcza nie lada trudności badaczom, podejmującym próby jej zdefiniowania. Złożoność tej problematyki wynika z wieloaspektowości i zarazem specyficzności JA, którego nie można określać jako stan, lecz jako proces, bowiem tożsamość podlega ustawicznym przemianom w trakcie rozwoju jednostki. Rozwój tożsamości następuje w oparciu o relacje społeczne i więzi emocjonalne w określonej grupie i kontekście społeczno-kulturowym, przy czym ta sama osoba zwykle jest członkiem wielu grup społecznych. Tożsamość silnie związana jest z systemem wartości, światopoglądem i przywiązaniem do tradycji, a także z cielesnością człowieka, kolorem skóry, rasą. Koncepcje holistyczne, w tym Gestalt ${ }^{34}$, podkreślają że poczucie tożsamości łączy w sobie zarówno pierwiastek duchowy, afektywny, racjonalny, społeczny jak i cielesny. Tożsamość ujawnia się w danym tu i teraz, a szczególnie daje o sobie znać podczas interakcji. Zrozumienie tych procesów komplikuje się jeszcze bardziej w zetknięciu z obcą kulturą, kiedy jednostka próbuje się do niej przystosować, bowiem reakcje i zachowania tuziemców, zwłaszcza negatywne, mogą wzmagać poczucie własnej odmienności w zakresie tożsamości.

Wielu autorów zakłada, iż JA człowieka składa się z różnych tożsamości $^{35}$. Tożsamość, jako rdzeń osobowości człowieka, podlega - jak on sam - określonym regułom rozwojowym. Najpierw, w procesie oddzielania się od rodziców, wykształca się u dziecka tożsamość osobista i zaczyna ono używać na swój temat pojęcia JA. Następnie, kiedy uświadamia sobie swą przynależność do grupy, rozwija się w nim tożsamość społeczna. Dopiero później następuje rozwój tożsamości narodowej i kulturowej, albowiem ich wykształcenie się u dziecka wymaga rozumienia pojęć abstrakcyjnych. Można, zatem, przyjąć według kryterium nabywania doświadczeń przez jednostkę, że tożsamość składa się z kilku, kolejno po sobie kształtujących się warstw: osobistej, społecznej, narodowej i kulturowej.

34 S. Ginger, Gestalt. Sztuka kontaktu. Optymistyczne podejście do relacji międzyludzkich, Warszawa 2004, s. 154.

35 Por. przykładowe koncepcje tożsamości w: W. G. Stephan, C. W. Stephan, op. cit.: (1) Tajfel i jego współpracownicy, s. 99; (2) Tuner, s. 111-112. Por. także: D. Ługowska, Problem tożsamości na tle wybranych koncepcji antropologicznych, w: Bezpieczeństwo człowieka a wielokulturowość, red. J. Dębowski, E. Jarmoch, A. W. Świderski, Siedlce 2008, s. 63-64. 
Tożsamość osobista - to aspekty JA, związane ściśle z osobowością człowieka, wynikające z indywidualnych cech w zakresie myślenia, emocji, zachowań, wyglądu i sposobów kontaktowania się ze światem, które różnicują go od innych jednostek z tej samej grupy i wytyczająjakość jego relacji interpersonalnych.

Ługowska, używając pojęcia tożsamości jednostkowej ${ }^{36}$, z jednej strony ma na myśli jej ścisły związek z kulturą i z poczuciem ciągłości JA $\mathrm{w}$ ontogenezie, z drugiej - afirmację określonych wartości, światopoglądu, filozofii życia, które wpływają na percepcję, interpretację świata i działanie człowieka. Nie sposób nie zgodzić się z myślą, dotyczącą ontogenetycznej ciagłości rozwoju JA. Ale należy podkreślić, iż percepcja człowieka stanowi swego rodzaju ,sito" dla subiektywnie przyjmowanych przez niego informacji, toteż, wpływając zwrotnie na interpretację otaczającego świata, pozwala budować własną filozofię życia. Jest to więc proces dwustronny, różnicujący poszczególne jednostki w tej samej grupie.

Tożsamość społeczna - to aspekty JA związane z przynależnością człowieka do grupy społecznej, szczególnie rodziny, z której się wywodzi, której normy i wartości internalizuje. Identyfikuje się on, w obrębie wykształconej już tożsamości osobistej, z dziedzictwem tej społeczności, zyskując w jej ramach poczucie swojskości, przynależności i jednocześnie poczucie odrębności od pozostałych grup w obszarze tej samej kultury.

Tajfel przedstawia tożsamość osobistą i społeczną jako aspekty nawzajem pozostające do siebie w opozycji ${ }^{37}$, tzn., że jeśli człowiek koncentruje się na sobie jako jednostce, nie może skupić się na swej tożsamości jako członka grupy. Nie sposób zgodzić się z tym do końca, gdyż zależnie od poziomu rozwoju samoświadomości i jej stanu w danym tu i teraz, osoba może mieć niski lub bardzo wysoki stopień kontaktu z własnym JA w obszarach obu tożsamości jednocześnie, a przy pełnej ich świadomości nie można wyeliminować jakiejś części siebie. Podczas interakcji z obcymi mogą ujawniać się i być rozwijane obie tożsamości, co można przedstawić na kontinuum: od bardzo słabego - do kontaktu pełnego z własnym JA na wszystkich jego poziomach. Jednak ich rozwój nie musi przebiegać równomiernie, a problem opozycyjności aspektów tożsamości u danej jednostki może dotyczyć osób, u których rozwój tożsamości jest w jakiś sposób ograniczony, zakłócony. Jakość tego procesu wyznaczają osobiste

36 D. Ługowska, op. cit., s. 64

37 W. G. Stephan, C. W. Stephan, op. cit., s. 99. 
kompetencje, związane z inteligencją emocjonalną i empatią oraz odpowiedni rozwój samoświadomości.

Tożsamość narodowa - to poczucie przynależności grupowej w sensie politycznym, wytyczonej granicami określonego państwa, niezależnie od etnicznego pochodzenia. Poczucie tożsamości narodowej niewątpliwie ulega wzmocnieniu w obliczu ważnych i wzniosłych wydarzeń państwowych, uwypuklając wtedy i podnosząc znaczenie tego aspektu tożsamości. Szczególne znaczenie przybiera ona w państwach wielonarodowych, gdzie inne grupy narodowościowe stanowią stałe tło dla indywidualnej tożsamości człowieka jako obywatela. W luźnym nawiązaniu do koncepcji Tunera $^{38}$ można przyjąć, że spośród kilku aspektów JA aktywizacji ulegnie JA narodowe (jako rodzaj JA grupowego) - JA, które daje poczucie przynależności politycznej i poczucie więzi z własnym narodem.

Tożsamość kulturowa - to świadomość przynależności do własnej grupy kulturowej w aspekcie tradycji, odrębności etnicznej, która stanowi „...kontynuację charakterystycznych dla poprzednich pokoleń sposobów myślenia, zachowania i działania, a także współdziałań zgodnych z uznawanymi wartościami i normami" ${ }^{\prime 39}$. Tenże aspekt tożsamości kształtuje przebieg interakcji jednostki zarówno w grupie własnej, jak i w kontaktach międzykulturowych. W relacjach z obcymi proces ten może przebiegać w przeciwstawnych kierunkach: do- lub od-, zależnie od nastawienia grupy.

Izabela Trzpil podkreśla, że podstawą tożsamości człowieka jest poczucie odrębności kulturowej. Daje to świadomość zakorzenienia i przynależności do własnej grupy kulturowej, a ich brak nierzadko wywołuje wiele negatywnych zjawisk natury psychologicznej, społecznej i politycz$n \mathrm{j}^{40}$. Zaś według E. Nowickiej „...ŚSwiadomość odrębności kulturowej jest rodzajem samoobrony przed [...] dominacją i globalizacją [...]"41, gdzie pielęgnowanie kultury i tradycji staje się kluczowym warunkiem dla utrzymania tożsamości indywidualnej i grupowej oraz pozycji własnej grupy w świecie. Świadomość ta pozwala podtrzymać tradycje kulturowe i żyć w zgodzie z jej wartościami. Jednak model tożsamości, proponowa-

38 Ibidem, s. 111.

39 A. Filipek, Tożsamość jako istotny element kultury bezpieczeństwa, w: Bezpieczeństwo człowieka a wielokulturowość, red. J. Dębowski, E. Jarmoch, A. W. Świderski, Siedlce 2008, s. 165.

${ }^{40}$ I. A. Trzpil, Wielokulturowość, różnorodność, powierzchowność - szansa czy zagrożenie?, w: Bezpieczeństwo człowieka a wielokulturowość, red. J. Dębowski, E. Jarmoch, A. W. Świderski, Siedlce 2008, s. 37. Por., G. Hofstede, op. cit. s. 304-306.

41 E. Nowicka, Świat człowieka-świat kultury, Warszawa 2006, s. 433-434. 
ny przez Nowicką, prezentuje obronny, lękowy charakter, który podczas kontaktów z obcymi może oddziaływać destrukcyjnie. Nadmiernie sztywne przywiązanie do norm i tradycji stanowi podstawę etnocentryzmu, tworząc zamknięty krąg własnej grupy. Szacunek dla własnej kultury nie musi zakładać braku postawy otwartości na różnorodność kulturową.

Zrozumienie pojęcia tożsamości komplikuje się jeszcze bardziej podczas realizacji bezpośredniego kontaktu międzykulturowego. Bowiem, równolegle do relacji interpersonalnej, zachodzą w procesie intrapsychicznym człowieka także interakcje wewnętrzne pomiędzy poszczególnymi aspektami jego tożsamości. Ponadto każda jednostka posiada swą odmienną i specyficzną dynamikę rozwoju. W oparciu o powyższe konkluzje oraz w zależności od kulturowo-politycznego kontekstu środowiska (państwowość mono- lub wielonarodowa), w jakim dana jednostka żyje i zdobywa doświadczenia, kolejność rozwoju aspektów tożsamości: narodowej i kulturowej nie musi być sztywno określona.

Następny aspekt tożsamości kulturowej różnicuje pojmowanie JA w zależności od nadawanych mu znaczeń w różnych grupach kulturowych. JA kulturowe definiowane jest inaczej w kulturach indywidualistycznych i kolektywistycznych ${ }^{42}$, a różnica wiąże się z odmiennością systemów wartości tych kultur. JA indywidualistyczne jest niezależne zarówno od innych jednostek w tej samej grupie, jak i od kontekstu społecznego, a jej unikalny zestaw cech osobowych otrzymuje społeczną aprobatę. Natomiast JA kolektywistyczne jest współzależne od grupy, bez której nie ma prawa bytu i cechuje się dążeniem do utrzymania z nią harmonijnej równowagi, ponieważ „Gwóźdź, który wystaje, zostanie przyklepany"43.

Poczucie odrębności i niepowtarzalności własnej kultury nie musi jednak być przeszkodą $\mathrm{w}$ rozwoju tożsamości kulturowej i w procesie międzykulturowej integracji.

\section{Kompetencje międzykulturowe a rozwój nowej tożsamości kulturowej w świetle badań własnych}

Kształtowanie się tożsamości kulturowej to proces zależny od wielu czynników, przy czym w ramach własnej grupy etnicznej obraz tożsamości kulturowej jej członków także może się różnić. Zróżnicowanie to zależy

\footnotetext{
42 W. G. Stephan, C. W. Stephan, op. cit., s. 128.

${ }^{43}$ Cyt. za: ibidem, s. 127.
} 
w dużym stopniu od możliwości doświadczania interakcji międzykulturowej lub jej braku. Tożsamość kulturowa najbardziej daje o sobie znać w sytuacji bezpośredniej konfrontacji z obcą kulturą, co dla różnych osób następuje w różnym okresie ich życia, czyli na innym etapie rozwoju ich tożsamości osobistej. Ponadto rodzaj i jakość indywidualnych doświadczeń międzykulturowych również wywiera wpływ na rozwój i obraz własnej tożsamości kulturowej, a ten pozostanie i tak odmienny w stosunku do osób, które nigdy nie doświadczały bezpośredniego kontaktu z przedstawicielem obcej grupy. Rozwój tożsamości cudzoziemca w procesie akulturacji wiąże się z dojrzałością jego osobowości, doświadczeniem i ze sposobem pojmowania przez niego własnego JA, dając w efekcie określony rodzaj kompetencji międzykulturowych.

Young Yun Kim, badając procesy akulturacji imigrantów koreańskich w USA określa, że adaptacja kulturowa zależy od następujących czynników $^{44}$ :

- czynniki bazowe: podobieństwo kultur, cechy osobowości, wiek, poziom wykształcenia;

- wzrost liczby kontaktów (częstotliwość);

- kompetencje własne odnoszące się do kultury gospodarzy.

Kompetencja dotycząca kultury gospodarzy obejmuje trzy wymiary:

1) wymiar poznawczy (znajomość języka, kody niewerbalne, wartości, symbole, wiedza);

2) wymiar afektywny (motywacja, orientacja emocjonalna i estetyczna, postawa wobec gospodarzy);

3) wymiar behawioralny (zdolność do mówienia, do słuchania, do stosowania reguł).

Wachlarz kompetencji interkulturowych jest bardzo szeroki i należałoby jeszcze zaliczyć doń takie czynniki, jak:

- uniwersalny charakter ekspresji podstawowych emocji, niezależny od kultury pochodzenia ${ }^{45}$;

- związek mowy ciała z emocjami oraz zdolność ich odzwierciedlania i budowania raportu ${ }^{46}$;

44 B. Ociepka za Y. Y. Kim, op. cit., s. 30.

45 E. Aronson, T. Wilson, R. Akert, Psychologia społeczna. Serce i umyst, 1997, s. $175-176$.

46 Odzwierciedlenie rozumiane tu jako sztuka nawiązania pełnego kontaktu z partnerem interakcji: Por.: W. Szewczuk, Stownik psychologiczny, Warszawa 1979, s. 174; A. J. Bierach, Mowa ciała kluczem do sukcesu, Wrocław 1997, s. 171-174. 
- spójność ekspresji emocji w zakresie komunikowania werbalnego i niewerbalnego;

- kompetencje językowe;

- umiejętność budowania i podtrzymywania kontaktu bez przekraczania granic partnera interakcji;

- otwartość na nowe informacje o człowieku z innej kultury (otwarte myślenie wbrew stereotypom);

- zdolność do autorefleksji;

- empatia;

- elastyczność;

- umiejętność dostosowania się do nowych warunków i sytuacji;

- akceptacja siebie i innych w aspekcie odmienności kulturowej;

- tolerancja dla sposobu myślenia i działania ludzi z obcego kręgu kulturowego;

- wrażliwość na różnice kulturowe połączona z chęcią ich poznawania bez wyrzekania się siebie i własnej kultury;

- szacunek dla tradycji kulturowej i wyznań religijnych tak własnych, jak i obcych;

- umiejętność rozróżniania problemów interkulturowych od innych;

- umiejętność rozwiązywania problemów;

- merytoryczne przygotowanie się do międzykulturowych spotkań;

- poczucie humoru jako forma zdrowego dystansu do samego siebie.

Ostatni czynnik - poczucie humoru - według badań psychologicznych ${ }^{47}$, ma szczególne znaczenie. Jest oznaką inteligencji i kreatywności, albowiem rozwijanie dobrze pojmowanego poczucia humoru:

- podnosi poziom kompetencji społecznych;

- daje narzędzie do radzenia sobie w sytuacjach trudnych i obniża poziom stresu;

- pozwala zastapić emocje negatywne pozytywnymi i rozwija pozytywne nastawienie;

- podnosi poziom empatii;

- poprawia stan zdrowia psychicznego i fizycznego.

Ponadto nie należy mylić konstruktywnego poczucia humoru z ironią i wyśmiewaniem. Dowcipy poniżające obcych to humor destruktywny. Bawi on ludzi o niskim poczuciu własnej wartości i niewielkiej wiedzy, którym zwykle brak autoironii i dystansu do siebie.

47 M. Świątkiewicz-Mośny, Spotkanie z humorem, „Forum akademickie” 2004, nr 4, s. 44. Por. M. Wallas, Poczucie humoru w psychoterapii, „Gestalt” 2000, nr 6. 
Zdolność do skutecznej komunikacji interkulturowej, w aspekcie komunikacji defensywnej i podtrzymującej ${ }^{48}$, dość jednostronnie ujmuje J. R. Gibb, dokonując jej analizy w oparciu o 6 par kategorii zachowań. Duże znaczenie przypisuje on klimatowi grupy, od którego uzależnia zachowanie jej członków. Niemniej prezentowane kategorie zachowań i tak odnoszą się do specyficznych cech i skłonności poszczególnych jednostek, a ich wypadkowa jednakowoż tworzy wspólny klimat grupy, wpływając w ten sposób zwrotnie na jakość kontaktu z obcymi.

Różnorodne koncepcje, dotyczące kompetencji międzykulturowych, podają wiele ich rodzajów. Mimo to, można je ująć w kilku podstawowych kategoriach: werbalne, niewerbalne, interpersonalne oraz wiedza o obcej kulturze. Zależą one od zasobów wewnętrznych cudzoziemca, dlatego indywidualny wymiar tych kompetencji ma ogromne znaczenie $\mathrm{w}$ aspekcie ustawicznego ich rozwijania w każdym $\mathrm{z}$ nas.

W odniesieniu do przedstawionych powyżej, praktycznych kompetencji interkulturowych, tożsamość kulturowa, to nie tylko konstrukt teoretyczny, lecz realny aspekt JA, który podlega dynamicznemu rozwojowi. Według Korporowicza „Tożsamość kulturowa nie jest [...] zamkniętą strukturą uwewnętrznionych znaczeń [...]. Jest raczej r e g u łą i c h a u to transform a c j i [...]. Tożsamość jest [...] procesem stawania się i wyboru siebie, procesem, który spaja i integruje różnorodne, cząstkowe identyfikacje w coś, co jest czymś więcej niż ich prostą sumą" "Z9. Zatem dobry, dojrzały kontakt z własną samoświadomością oraz ustawiczna zdolność do jej rozwoju pozwala na autonomiczne samookreślenie się w nowych warunkach kulturowych, a otwarta, kreatywna postawa umożliwia wypracowanie własnej reguły autotransformacji ${ }^{50}$. Ta optymistyczna koncepcja pozwala wierzyć, że człowiek jest w stanie doskonalić swe kompetencje międzykulturowe oraz wypracowywać nowe reguły, efektywne dla rozwoju swej tożsamości kulturowej.

Koncepcja Wolfganga Welscha, której głównym założeniem jest przemieszanie i wzajemne przenikanie się kultur aż po rdzeń $^{51}$ pokazuje po-

48 J. R. Gibb, Komunikacja defensywna, w: Mosty zamiast murów. O komunikowaniu się między ludźmi, J. Stewart, Warszawa 2000, s. 504-509.

49 Cyt. za: L. Korporowicz, Od konfliktu do spotkania kultur, czyli tożsamość jako reguła autotransformacji, w: Komunikacja międzykulturowa. Zbliżenia i impresje, A. Kapciak, L. Korporowicz, A. Tyszka, Warszawa 1995, s. 35.

50 Ibidem, s. 39-40.

51 W. Welsch, Transkulturowość. Nowa koncepcja kultury, „Studia Kulturoznawcze" 1998, t. 10, s. 203. 
nadto, że ,inne” kultury stają się stopniowo wewnętrznymi treściami „własnej” kultury, absolutna obcość już nie istnieje ${ }^{52}$. Fakt, że nie można kultury pojmować jako jednorodnej i wyraźnie zarysowanej, powoduje dalsze konsekwencje dla rozumienia pojęcia tożsamości, która jawi się jako tymczasowa, podlegająca nieustającym przeobrażeniom przestrzenna sieć transkulturowa, zawierająca $\mathrm{w}$ sobie alternatywne elementy ${ }^{53}$. Koncepcja transkulturowości zakłada wielość możliwych tożsamości. Człowiekowi przywrócone zostaje prawo do kulturowego określenia się i wyjścia poza wszelkie monokulturowe formacje i struktury ${ }^{54}$, poza jednorodność własnej kultury, języka, etniczności. Zatem nie musi to oznaczać zagubienia cudzoziemca w obcej kulturze, ponieważ zwykle asymiluje on tyle, ile jest w stanie osobiście przyjacć i zinternalizować.

Jednostka jako aktywny i świadomy podmiot działania może mieć wpływ, zarówno pozytywny, jak i negatywny, na swe procesy wewnętrzne oraz na jakość relacji z członkami obcej kultury. Bariery wewnętrzne można pokonać osobiście, jeżeli są przez cudzoziemców uświadamiane. Wtedy dokonywanie zmian w sobie umożliwia doskonalenie kompetencji interkulturowych. Wiąże się to z osobistą odpowiedzialnością za skutki własnych decyzji i działań w dążeniu do osiągnięcia satysfakcjonującej akulturacji. Tego typu prawidłowość rejestruje cytowane badanie pilotażowe, w aspekcie zmiennych: lęk-cecha (LC) i stres akulturacyjny (SA). Badani z podwyższonym LC i SA uzyskują wyższy poziom akulturacji (PA), mimo, iż jako osoby lękowe wykazują tendencję do stosowania mniej skutecznego stylu zaradczego - SSE. Uzyskane wartości korelacji sugerują również skłonność cudzoziemców lękowych do posługiwania się stylem PKT, czyli dążeniem do otrzymania wsparcia w celu redukcji napięcia, związanego ze stresem akulturacyjnym. Chociaż owe dane wydają się zaskakujące i pozornie sprzeczne, przypuszczalnie mogą mieć wspólny mianownik.

Otóż najwyższy wynik akulturacji uzyskują osoby, które dokonują zmiany wewnętrznej, ze wzrostem dochodów oraz żyjące z rodziną lub partnerem z nowej kultury. Osiagnnięcie lepszej akulturacji niewątpliwie wymaga dużego zaangażowania i wysiłku zaradczego (także na płaszczyźnie zawodowej), co pociagga za sobą odczuwalne koszty na poziomie psychologicznym i, często, fizjologicznym - w postaci silniejszego stresu. Toteż tendencja do stosowania stylu PKT może być związana z silną po-

$\begin{array}{ll}52 & \text { Ibidem, s. } 205 . \\ 53 & \text { Ibidem, s. } 221 . \\ 54 & \text { Ibidem, s. } 209 .\end{array}$ 
trzebą przynależności i wsparcia, których zaspokojenie staje się możliwe w przypadku posiadania rodziny/partnera z nowego kraju pobytu. I chociaż, z drugiej strony, nowa kulturowo rodzina wyzwala konieczność przystosowania się doń, a to wzmaga stres, w efekcie owocuje dobrym PA cudzoziemców. Zatem można założyć, iż u osób z podwyższonym lękiem-cechą, żyjących w związkach dwukulturowych i deklarujących dokonanie zmiany wewnętrznej, rodzi się potrzeba autotransformacji w obszarze ich tożsamości kulturowej. Odwrotnym potwierdzeniem tego faktu jest niska wartość PA osób świadomych własnych barier wewnętrznych, które jednak nie deklarują potrzeby zmiany.

Dokonanie zmiany wewnętrznej można potraktować z jednej strony jako strategię poradzenia sobie w obcej kulturze, co wzbogaca wiedzę o akulturacyjnym repertuarze zaradczym. $Z$ drugiej-należy podkreślić jej znaczenie dla dalszego rozwoju tożsamości, gdyż wysiłek zaangażowany w jej dokonanie, nie może pozostać obojętny dla systemu wartości jednostki. Wnioski pokazują, iż posiadanie bliskiej relacji, która daje wsparcie i poczucie bezpieczeństwa, ułatwia asymilację elementów obcej kultury i pomaga pokonywać trudności akulturacyjne. Małżeństwo dwukulturowe stanowi, bowiem, swoisty, międzykulturowy mikroświat, gdzie, w oparciu o proces wyrównywania różnic kulturowych, wzajemnie przenikają się elementy obu kultur, uruchamiając proces dążenia do kulturowego ujednolicenia jego członków ${ }^{55}$. Różnorodne strategie adaptacyjne podejmowane przez partnerów w małżeństwach dwukulturowych w różnym stopniu sprzyjają wzajemnemu zbliżeniu. Strategia „twórczego przystosowania" Tsenga ${ }^{56}$ pokazuje możliwość osiąnięcia maksymalnego ujednolicenia kulturowego, gdy partnerzy, rezygnując z własnych norm kulturowych, tworzą zupełnie nowe wzory zachowania. Wtedy, w konkluzji, dzięki procesowi autotransformacji mentalnie zmienia się u cudzoziemca pojęcie ojczyzny i własnej tożsamości kulturowej, które ulegają rozszerzeniu. A nowa rodzina ułatwia ów proces bardziej niż jej brak, gdyż, w myśl koncepcji dyfuzji Lintona, elementy nowej kultury przejmowane są przede wszystkim na styku bezpośredniej relacji przedstawicieli różnych kultur ${ }^{57}$.

55 T. Paleczny, Interpersonalne stosunki międzykulturowe, Kraków 2007, s. 42.

56 D. Matsumoto, L. Yuang, op. cit., s. 490. Por. osobowość jako organizacja twórczo i adekwatnie przystosowująca się do zmian w: K. Obuchowski, Adaptacja twórcza, Warszawa 1985, s. 195-202.

57 R. Linton, Dyfuzja, w: Elementy teorii socjologicznych, W. Derczyński, A. Jasińska-Kania, J. Szacki, Warszawa 1975, s. 265. 
Lęk akulturacyjny $\rightarrow$ Stres akulturacyjny $\rightarrow$ Potrzeba afiliacji $\rightarrow$ Zalożenie rodziny dwukulturowej $\rightarrow$ Potrzeba przystosowania się $\rightarrow$ Dokonanie zmiany wewnętrznej jako strategia poradzenia sobie $\rightarrow$ Rozwój nowej tożsamości kulturowej $\rightarrow$ Integracja z nową kulturą.

Rys. 1. Hipotetyczny przebieg procesu rozwoju tożsamości kulturowej osób o podwyższonym poziomie lęku akulturacyjnego

W oparciu o powyższą analizę można założyć hipotetyczny mechanizm rozwoju nowej tożsamości kulturowej, której kierunek prowadzi ku integracji z nową kulturą (rys. 1). Cudzoziemiec, przekraczając ograniczenia w samym sobie oraz pokonując ciasny gorset kulturowych uwarunkowań i zasad, dokonuje autotransformacji, która nabiera tu znaczenia nowej kompetencji interkulturowej i stwarza jednocześnie możliwości dla rozwoju międzykulturowych procesów integracyjnych.

\section{Procesy integracyjne w aspekcie lęku akulturacyjnego i rozwoju tożsamości kulturowej}

Integracja kulturowa to proces dynamiczny, uwarunkowany wieloczynnikowo, który związany jest w dużej mierze $\mathrm{z}$ dokonywaniem przez cudzoziemca zmian w sobie. W tym aspekcie kompetencje wewnętrzne, wpływając na jego akulturację w obcym kraju, pozwalają osiagnnąć określoną formę asymilacji kulturowej. Mechanizm ten jest złożony i ma charakter sprzężenia zwrotnego: łatwość asymilacji może wpływać na poziom osiagnniętej integracji oraz odwrotnie - ewoluujący proces integracji z nową grupą kulturową pozwoli uzyskać lepszy poziom asymilacji. Kształtowanie się własnej tożsamości kulturowej także podlega swoistej ewolucji, dlatego skuteczność akulturacyjna, zależnie od stopnia kreatywności cudzoziemca, może znaleźć wyraz w określonych formach integracji z obcą grupą.

Jednakże w praktyce osiagnięcie pełnej integracji nie jest tak proste, jak to przedstawia założenie teoretyczne (rys. 1). Lęk akulturacyjny, zależnie od swego natężenia, może powodować różne konsekwencje dla integracji obcokrajowców w obcym kraju. Podwyższony jego poziom, który jest przedmiotem tej analizy, może oddziaływać dwojako - prowadzić 
w kierunku izolacji, albo wzmagać potrzebę przynależności do nowej grupy:

1. Izolacja zamyka cudzoziemca na nową kulturę, budzi dystans, wrogość i agresję, które mogą przejawiać się nie tylko w postaci negatywnych emocji, ale także czynnych działań wymierzonych przeciwko tuziemcom. Jest ona zagrażająca dla gospodarzy ale, jeśli przyjmie postać autoagresji, może być szkodliwa dla wyobcowanego przybysza.

2. Potrzeba przynależności, z kolei, skłania do poszukiwania bezpiecznej niszy np. w postaci rodziny z nowej kultury, która gwarantuje oparcie i poczucie bezpieczeństwa. Ten kierunek umożliwia jednocześnie lepszą integrację oraz asymilację na wyższym poziomie.

Izolacja może nastąpić z własnej decyzji cudzoziemca lub z powodu wykluczenia go przez tuziemców. W obu przypadkach zaburza przystosowanie i przejawia się asymilacją negatywną, wywołując szereg negatywnych reakcji: wrogość, nasilenie lęku, także bezradność, depresję i brak akceptacji dla wartości obcej kultury. Poczucie wykluczenia może prowadzić w kierunku: kontroli, złości, nienawiści, czynnej agresji, szkodliwych działań, w tym aktów terrorystycznych pod adresem nowego państwa i jego obywateli. Aczkolwiek te działania mogą mieć charakter zaplanowany, w których przybysze celowo nie zakładają swej integracji z nową kultura, a wręcz zamierzają jej szkodzić.

Natomiast w przypadku lęku o niższym poziomie, przy akceptacji wartości nowej kultury, obcokrajowiec może osiągnąć adaptację opartą na konformizmie, której celem jest pozyskanie aprobaty tuziemców, co w efekcie umożliwia osiągnąć asymilację zrównoważoną.

$\mathrm{Z}$ kolei, nawet, gdy cudzoziemiec odczuwa pewien poziom lęku, lecz wierzy w siebie i w dobre intencje tuziemców, akceptuje przy tym wartości nowej kultury oraz dokonuje zmian w obszarze swej tożsamości, taka kreatywność jego postawy w procesie akulturacji pozwala osiagnąć asymilację pozytywną oraz zintegrować się z nową społecznością. Ostatecznie dzięki rozwojowi osobistemu wykształca on w sobie tożsamość dwukulturową. Osiągnięcie optymalnej integracji okazuje się być możliwe w oparciu o więzi emocjonalne w małej, spójnej grupie społecznej, jaką jest rodzina dwukulturowa.

W związku z powyższym można wyróżnić następujące poziomy integracji cudzoziemców w nowej kulturze pobytu:

Brak integracji - to poczucie osamotnienia, izolacja, napięcia, negatywne emocje: wrogość i lęk; dystans, rezerwa, rywalizacja i antagonizm; brak poczucia bezpieczeństwa i brak zaufania, które nie muszą wynikać 
z realnego zagrożenia; także konieczność przetrwania bez akceptacji wartości nowej kultury. Postawa ta może wynikać z własnego wyboru lub z powodu wykluczenia przez tuziemców. Stan wykluczenia może dotyczyć jednostki lub całej grupy kulturowej na różnych płaszczyznach życia jednocześnie, co wzmaga dążenie do poszukiwania oparcia w grupie własnej. Podtrzymuje to silną identyfikację z własną grupą pochodzenia i swą pierwotną tożsamością kulturową oraz wyzwala wysoką koncentrację na współpracy, spójności i harmonii wewnątrz własnej grupy kulturowej, zabarwioną poczuciem wyższości wobec tuziemców. Taka postawa może nasilać się z czasem jeszcze bardziej i prowadzić do alienacji oraz anomii psychicznej jednostki ${ }^{58}$, powodować hermetyczne zamykanie się we własnej enklawie, jak również prowadzić do anomii politycznej, czyli utraty sensu polityczno-społecznego. Podłożem silnego poczucia obcości może być wysoki poziom etnocentryzmu, uprzedzeń i brak tolerancji dla odmienności kulturowych, co rzutuje na jakość podejmowanych działań, które przybierają charakter biernego oporu i wycofania, albo czynnej agresji w postaci spiskowania i aktów terroru pod adresem nowego państwa.

Zludzenie integracji - to nierealistyczna wiara w przetrwanie bez uzasadnienia w posiadanych przez cudzoziemca, szeroko rozumianych, kompetencjach międzykulturowych, która jednak, mimo doświadczanych trudności, daje możliwość egzystencji w nowej kulturze. Towarzyszy jej zamieszanie wewnętrzne i trudność odnalezienia się w obszarze własnej tożsamości (Kim jestem?). Ponadto nieprzewidywalność stosunków międzyludzkich, przy niskiej samoświadomości jednostki, może prowadzić do wielu frustracji i nieporozumień. Relacje i aktywność na rzecz współdziałania z tubylcami mają charakter przypadkowy. Więzi społeczne są słabe, powierzchowne i nietrwałe, chociaż może być ich wiele. Osoba bierze za dobrą monetę wszystko, co wydaje się być pozytywne. Model tożsamości oparty jest tu na przypadkowym charakterze doświadczeń życiowych oraz poczuciu kontroli zewnętrznej (Jakoś to będzie.). Taka postawa wynika z lęku przed samotnością w obcym świecie, lecz w efekcie doznawanych rozczarowań, może pogłębiać poczucie osamotnienia.

Integracja bierna - to powierzchowna, deklaratywna akceptacja norm i wartości nowej kultury mimo poczucia niezadowolenia; dominuje bierność i brak zaangażowania oraz konformistyczna - wynikająca z lęku - zgoda na współistnienie różnych postaw i racji, żeby nie zrazić do siebie

58 T. Paleczny, op. cit., Kraków 2007, s. 167. 
tuziemców. To postawa, w której pojawia się aktywność o charakterze instrumentalnym - podejmowana w aspekcie osiagnnięcia korzyści osobistych, niekoniecznie zgodnie z prawem - możliwa dzięki uruchomieniu kompetencji taktycznych jednostki. Jej adaptacja skupia się na realizacji własnych podstawowych celów i wykazuje charakter gry, w której inni mają znaczenie, jeśli okazują się przydatni. Na tym etapie cudzoziemcy bardziej są odbiorcami niż uczestnikami nowej kultury, a ich relacje, powierzchowne i nietrwałe, mają charakter krótkoterminowy przy dużej gotowości i łatwości do zrywania, jeśli nie idą w parze z interesem osobistym. W dalszym ciagu czują się jako goście, a ich tożsamość, w aspekcie akulturacji, wynika z poczucia tymczasowości i jest słabo zakorzeniona w nowej kulturze.

Integracja czynna - to uznanie wartości kultury nowego kraju, rozwijanie swych kompetencji międzykulturowych; podejmowanie inicjatyw integracyjnych w celu pozyskania akceptacji tuziemców. Postawa ta może wynikać nie tylko z potrzeby afiliacji, lecz również chęci uzyskania lepszej pozycji społecznej, z ambicji wybicia się oraz potrzeby wpływu społecznego, chęci przewodzenia. Ponadto może się opierać na mechanizmie identyfikacji z konkretnym przedstawicielem nowego kraju pobytu, prezentującym cechy i wartości, do których obcokrajowiec aspiruje. Relacje, dzięki zaangażowaniu i lojalności, zaczynają mieć charakter długoterminowy, dając w efekcie obustronną satysfakcję. Cudzoziemiec rozwija swą ciekawość poznawczą i współdziałanie oraz uznaje politykę nowego kraju za ważną dla siebie sferę życia.

Integracja pelna - to internalizacja wartości i norm nowej kultury, świadome zaangażowanie społeczne, przy efektywnej realizacji celów osobistych; duża gotowość do edukacji i poznawania nowej kultury. Postawa tolerancji dla odmiennych systemów wartości i poglądów oraz wzajemnego poszanowania granic i godności, przy pozytywnej samoocenie i wewnętrznej kontroli, rzutuje pozytywnie na procesy akulturacyjne. Dążenie do równowagi w relacjach pomaga w godzeniu kulturowej różnorodności i pozwala harmonijnie współdziałać z tuziemcami. Dokonywanie zmian wewnętrznych w zakresie własnej tożsamości podnosi poczucie pewności siebie, świadomość skuteczności swych działań i poczucie zakorzenienia w nowej ojczyźnie. Doświadczanie wzajemnego szacunku oraz zdolność do dialogu międzykulturowego daje w efekcie zgodę na współistnienie międzykulturowe oraz, z uwagi na świadomość wspólnego losu, gotowość do poszukiwania rozwiązań w sytuacjach konfliktowych. Kultywacja własnych wartości nie przeszkadza w asymilacji nowych, 
prowadząc do ukształtowania się tożsamości dwukulturowej. Na tym etapie cudzoziemcy wykazują szeroko rozumiane zaangażowanie na różnych płaszczyznach życia. W dążeniu do pokojowego współistnienia owocuje to bezkolizyjnym połączeniem zaangażowania w realizację zarówno własnych inicjatyw społeczno-politycznych, jak i podejmowanych przez gospodarzy. Wysoka świadomość polityczna motywuje do aktywności o charakterze partycypacji politycznej. Dzięki postawie autentycznego zaangażowania stają się gospodarzami w nowym kraju pobytu.

Wymienione rodzaje integracji można odnieść do coraz wyższego poziomu przystosowania akulturacyjnego, gdzie proces autotransformacji w obszarze tożsamości obcokrajowca odgrywa istotną rolę. Wraz z upływem czasu pobytu i dzięki wysokiej samoświadomości asymiluje on coraz więcej elementów nowej kultury, by w najwyższym stadium integracji poczuć się obywatelem nowego kraju w pełnym znaczeniu tego słowa. Należy podkreślić, że proces integracji jest wartościowy i efektywny pod warunkiem dobrowolności, kiedy nie podlega żadnej presji.

W procesie wzajemnego zbliżenia różnych grup kulturowych duże znaczenie ma poczucie wspólnego losu. Badania wykazują, że kontaktom interkulturowym sprzyja współpraca przedstawicieli obcych kultur podczas wytyczania i realizacji wspólnego celu, który stanowiłby dla nich nadrzędny interes i wspólne dobro. Warunkiem sukcesu wspólnego działania jest także wyrównywanie różnic $\mathrm{w}$ zakresie pełnionych przez nich funkcji (równy status). Służy to integracji w dużym stopniu, albowiem minimalizuje czynnik rywalizacji, który może pogłębiać antagonizmy kulturowe ${ }^{59}$. Wielki eksperyment, dotyczący desegregacji w szkołach amerykańskich $^{60}$, przeprowadzony w USA na skalę państwową pokazał, że współzawodnictwo pomiędzy grupami mieszanymi kulturowo nie wywiera szkodliwego wpływu kulturowego, pod warunkiem, że kończy się sukcesem. Ponadto współpraca w zespołach mieszanych kulturowo sprzyja kształtowaniu przychylnych postaw wobec przedstawicieli obcych grup ${ }^{61}$. Inne badania - Gaertnera i Dovidio - wykazują, że jeśli w skład grupy nadrzędnej wchodzi grupa własna i obca, wytwarza się w niej poczucie wzajemnej przynależności, a to sprzyja obniżeniu poziomu uprzedzeń ${ }^{62}$.

\footnotetext{
59 M. Wallas, Dialog międzykulturowy..., op. cit., s. 264.

60 W. G. Stephan, C. W. Stephan, op. cit., s. 95.

61 Ibidem, s. 97.

62 Ibidem, s. 120.
} 
Przeprowadzony przez autorkę eksperyment w grupach AAL, podobnie pokazał, iż wspólne działanie nad wypracowaniem przykładów budowania dialogu międzykulturowego pozwoliło uzyskać lepszy wynik w grupie wielokulturowej niż w monokulturowej. Dla grupy wielokulturowej stanowiło cel nadrzędny, priorytet służący dobru ogólniejszemu, z uwagi na świadomość wspólnego losu. Uczestnicy tej grupy na bieżąco doświadczali różnic kulturowych. Dlatego w dążeniu do osiągnięcia wytyczonego celu uwzględniali potrzeby reprezentantów wszystkich kultur, budując klimat bezpieczeństwa i wzajemnej tolerancji, co w efekcie dało wysoką jakość wykonanego zadania ${ }^{63}$. Ponadto dążenie do wspólnego sukcesu grupy mieszanej kulturowo podniosło poziom jej integracji, przejawiając się dużym zaangażowaniem, wysokim poczuciem humoru, wzrostem poziomu energii w grupie i wzajemnej sympatii. Natomiast to samo zadanie w grupie monokulturowej nabrało innego znaczenia, gdyż nie wymagało podjęcia współpracy z obcymi. Większe skupienie na potrzebie spójności, niż na treści zadania, mogło w tej grupie znacznie osłabić motywację zadaniową i uzyskane rezultaty ${ }^{64}$.

Lęk akulturacyjny jest jednym spośród wielu wyznaczników poziomu akulturacji oraz integracji. Nawet przy pełnej integracji nie musi zanikać, jeśli jest cechą osobowości. Jednak, nawet, gdy utrzymuje się on na pewnym poziomie, jego wartości nie muszą zaburzać funkcjonowania jednostki, a mogą wręcz stanowić czynnik mobilizacyjny dla konstruktywnego działania. Natomiast brak lęku cechuje zwykle jednostki psychopatyczne o skłonnościach antyspołecznych. To one, z własnego wyboru, nie odczuwają potrzeby integracji z nową kultura, a nierzadko ich migracja wiąże się z celową, intencjonalnie wrogą aktywnością, której przejawem są akty terroryzmu.

Integracja jest efektywniejsza, gdy imigranci zyskują w obcej kulturze nowe, cenne - dla samorealizacji - wartości. Wymieniane najczęściej przez uczestników badania pilotażowego, nabyte nowe wartości, to: umiejętność radzenia sobie z trudnościami i adaptacji do różnych sytuacji, nauka nowego języka, nowe przyjaźnie, współpraca z tuziemcami oraz doświadczanie miłości w nowych związkach ${ }^{65}$.

$\mathrm{W}$ procesie integracji, związki dwukulturowe, w większym stopniu motywują cudzoziemców do zmiany wewnętrznej. Chociaż proces wza-

\footnotetext{
63 M. Wallas, Dialog międzykulturowy..., op. cit., s. 267.

64 Ibidem, s. 269.

65 M. Wallas, artykuł w druku.
} 
jemnego przystosowania nie jest łatwy, bowiem dotyka różnic osobowości, postaw i systemów wartości, ukształtowanych przez odmienne kultury, małżeństwa dwukulturowe dają szansę lepszej integracji niż pobyt samotny. Wsparcie ze strony nowej rodziny pociaga za sobą akceptację szerszej społeczności lokalnej, a to umożliwia uzyskanie satysfakcjonującej pozycji społecznej i daje poczucie przynależności do nowej grupy kulturowej. Pomaga także w nabywaniu nowych kompetencji interkulturowych w postaci norm i reguł, stosowanych rytuałów, których przestrzeganie podnosi poziom wzajemnego zaufania oraz gwarantuje zapewnienie bezpieczeństwa w nowo stworzonej rodzinie, a to służy utrzymywaniu związków wg zasad i norm kultury gospodarzy.

Podsumowując, rodzaj osiagniętej przez cudzoziemca integracji kulturowej, w jego indywidualnym wymiarze, zależy m.in. od:

- względnie stałych właściwości temperamentu i cech osobowości jednostki, wyznaczających styl zachowania;

- poziomu samoświadomości;

- odporności na stres akulturacyjny;

- skuteczności stosowanych sposobów zaradczych;

- rodzaju motywacji związanej z pobytem;

- umiejętności rozwijania szeroko pojmowanych kompetencji międzykulturowych;

- dążenia do rozwoju własnej tożsamości i zdolności autotransformacji kulturowej.

Ponadto należy podkreślić, że integracja kulturowa w nowym środowisku, jako specyficzny dla danej jednostki proces indywidualny, wymaga czasu, żeby zakorzenić się według osobistych możliwości i własnego tempa. Aczkolwiek, czas może być z jednej strony sprzymierzeńcem i prowadzić ku asymilacji pozytywnej, lub z drugiej - potęgować nasilanie się, osiągniętej od początku asymilacji negatywnej. Warto jednak ufać, że większość imigrantów, dzięki własnym kompetencjom oraz potrzebie autotransformacji, potrafi sprostać wymogom kulturowym, by zintegrować się z nową kulturą.

\section{Uwagi końcowe}

Lęk, jako rys osobowościowy cudzoziemców, jest emocją, która ogranicza. Nasilając doświadczanie stresu akulturacyjnego, stanowi barierę w kontaktach międzykulturowych. Jednakże osoby o podwyższonym jego 
poziomie, przy odpowiednio rozwijanych kompetencjach interkulturowych, mają szansę uzyskać zadowalające wyniki integracji i asymilacji kulturowej. Satysfakcja osobista z osiągnięcia określonej pozycji społecznej w nowym kraju jest potwierdzeniem efektywności ich wysiłku akulturacyjnego.

Wstępne testowanie hipotezy dotyczącej wpływu lęku akulturacyjnego na rozwój nowej tożsamości kulturowej i procesy integracji cudzoziemców w obcej kulturze wykazuje, iż, jednostki lękowe, które potrafią wykorzystać pozytywne skutki stresu akulturacyjnego, uzyskują lepsze efekty akulturacyjne. Szeroko rozumiane kompetencje interkulturowe, jak: wysoki poziom samoświadomości, zaangażowanie i wysiłek, empatia, umiejętność przystosowania się do nowych sytuacji, elastyczność i kreatywność w poszukiwaniu nowych rozwiązań, rozwijanie nowych strategii zaradczych, także umiejętność rozwiązywania konfliktów i praca nad sobą, mimo podwyższonego lęku akulturacyjnego, mobilizują do pokonywania wewnętrznych ograniczeń. Dokonywanie przewartościowań i zmian we własnym systemie wartości jest nie tylko przykładem wypracowania specyficznej reguły autotransformacji, która w efekcie pomaga w rozwoju nowej tożsamości kulturowej oraz integracji w obcym środowisku. To także nowa przesłanka dotycząca indywidualnych strategii zaradczych w aspekcie pozytywnych skutków stresu akulturacyjnego.

Czynnikiem sprzyjającym w tym procesie jest zawieranie dwukulturowych małżeństw i związków partnerskich. Cudzoziemcy z potrzebą przynależności i wsparcia wykazują większą skłonność do budowania związków długoterminowych. Konieczność przystosowania się do nowej rodziny, chociaż powoduje stres, wyzwala motywację do utrwalania relacji, uczy wzajemnej akceptacji i tolerancji oraz sprzyja wzajemnemu kulturowemu zbliżaniu się partnerów w procesie wyrównywania różnic. Tym samym u obcokrajowców zmienia się i ulega rozszerzeniu pojęcie własnej tożsamości w kierunku tożsamości dwukulturowej.

Postawy wzajemnej tolerancji obcokrajowiec uczy się nie tylko w nowej rodzinie. Częste podróżowanie i przebywanie wśród różnych kultur pomaga w otwieraniu się na obcych, uczy szacunku dla inności. Prawidłowy kontakt zakłada poszanowanie różnic i granic wzajemnych, nie tylko terytorialnych, lecz osobistych. Szacunek dla partnera interakcji oraz dla samego siebie nie zakłada deprecjacji którejkolwiek ze stron. Wrażliwość na różnice kulturowe, połączona z chęcią ich poznawania nie bierze pod uwagę konieczności zaprzeczania własnym wartościom, wyrzekania się siebie i własnej kultury. Ponadto asymilowanie nowych wartości 
sprzyja modyfikowaniu własnej postawy podczas budowania stosunków partnerskich w interkulturowym dialogu.

Umiejętność radzenia sobie z lękiem i stresem akulturacyjnym sprzyja otwartości na kontakt międzykulturowy, inspiruje do nawiązywania coraz to nowych relacji, zachęca do podejmowania nowych wyzwań i ról na płaszczyźnie społecznej, zawodowej i politycznej prowadząc tym samym $\mathrm{ku}$ coraz lepszej integracji $\mathrm{z}$ tuziemcami w nowym kraju pobytu.

Międzykulturowe współistnienie wywołuje wiele trudności i wymaga rozwiązań. Problemy integracji dotyczą tak samo imigrantów i tuziemców, a ostateczny rezultat jest wypadkową wektorów postaw obu stron. Pokonywanie ich we wspólnym trudzie, sprzyja osiaganiu wyższego poziomu samorozwoju jednostek i grup. Człowiek jest częścią kultury, ale jako istota kreatywna, także jej współtwórcą. Jakość kontaktów międzykulturowych zależy od każdego, kto w nich uczestniczy. Owocna współpraca wymaga wzajemnego poznawania, zrozumienia i zaangażowania. A ponieważ współdziałanie kultur oraz wzajemna wymiana wszelakich dóbr i wartości staje się niezbędnym warunkiem rozwoju każdej z nich, dlatego wymaga zaakceptowania poczucia wzajemnej zależności i wspólnego losu.

Kultury, tak samo jak ich członkowie, podlegają ustawicznym przemianom, toteż proces przyswajania wiedzy na ich temat również cechuje dynamiczny charakter. Wielokulturowość i umiejętność podejmowania efektywnego dialogu wyznacza cele i zadania nie tylko w sferze międzykulturowych koncepcji teoretycznych, lecz wymaga podejmowania i realizacji konkretnych działań na szczeblach administracji państwowej w postaci zarządzeń prawnych, a także oddziaływań edukacyjnych, które uwzględniają - począwszy od najmłodszych - kolejne grupy wiekowe. Systemy edukacyjne wielu państw starają się wypełnić tę lukę poprzez zatrudnianie nauczycieli i wykładowców różnych ras i narodowości oraz przez wprowadzanie nowych przedmiotów, dotyczących komunikowania międzykulturowego, np. różnego rodzaju treningi komunikacji międzykulturowej. Działania te, w zakresie podnoszenia kompetencji międzykulturowych, mają na celu zmniejszać dystans między obcymi grupami i niwelować lęk akulturacyjny.

Poczucie bezpieczeństwa międzygrupowego współcześnie nie jest już tylko kwestią fizycznego przetrwania, lecz zapewnienia niezbędnych możliwości rozwojowych różnym grupom kulturowym. Zatem w czasach intensywnych migracji z uwagi na poczucie stabilności i bezpieczeństwa obu stron - zarówno imigrantów, jak i tuziemców - koniecznością jest 
monitorowanie tego procesu w celu odpowiedniego ukierunkowania polityki państwa w postaci nie tylko regulacji prawnych, oddziaływań edukacyjnych, lecz także stworzenia przestrzeni dla porozumienia opartego na współpracy i kooperacji, bowiem te środki najlepiej służą budowaniu wzajemnego zaufania i zapobieganiu konfliktom. Małżeństwa dwukulturowe również odgrywają w tej kwestii szczególne znaczenie. Są one gwarantem bezpieczeństwa politycznego, gdyż cudzoziemiec nie będzie szkodził własnej rodzinie, albowiem ta stanowi dla niego ważną wartość, niezależną od kultury pochodzenia.

Niniejsza wypowiedź skupia się na omówieniu problemów, dotyczących związku między kształtowaniem się nowej tożsamości kulturowej a efektywnością procesów integracyjnych cudzoziemców. Jednak proces przystosowania kulturowego dotyczy tak samo tuziemców - członków społeczeństwa przyjmującego, u których pojawienie się obcych przybyszów wywołuje stres i emocje, budzi lęk i obniża poczucie bezpieczeństwa. Poczucie zagrożenia może się wiązać $\mathrm{z}$ realnym niebezpieczeństwem lub też z przewidywaniem negatywnych skutków ze strony zachowań cudzoziemców np. dominacji na rynku pracy, dostępu do wspólnych dóbr, czy - w ekstremalnych przypadkach - aktów terroryzmu. Wszelkie obawy i negatywne wyobrażenia pogłębiają stereotypowe myślenie na temat obcych i utwierdzają w uprzedzeniach. Dlatego problem pokojowego współistnienia wymaga ustawicznych zmian w systemach edukacyjnych, jak również modyfikacji rozporządzeń rządowych w tym obszarze.

Przedstawione wnioski, dotyczące znaczenia lęku i stresu akulturacyjnego w procesie kształtowania tożsamości kulturowej oraz integracji w obcej kulturze, stanowią ważną przesłankę w spojrzeniu na proces integracji międzykulturowej, toteż inspirują do pogłębienia działań badawczych w tym kierunku.

\section{Bibliografia}

Armstrong M., Zarzadzanie zasobami ludzkimi. Strategia i działanie, Kraków 1996. Aronson E., Wilson T., Akert R., Psychologia spoleczna. Serce i umyst, Warszawa 1997. Bąk W., Oleś P., Lęk w kontekście samoregulacji, w: Lęk, geneza, mechanizmy, funkcje, red. M. Fajkowska, B. Szymura, Warszawa 2009.

Bernard H. S., MacKenzie K. R. (red.), Podstawy terapii grupowej, Gdańsk 2003.

Bierach A. J., Mowa ciała kluczem do sukcesu, Wrocław 1997.

Brzeziński J., Elementy metodologii badań psychologicznych, Warszawa 1978. 
Corey M. S., Corey G., Grupy. Zasady i techniki grupowej pomocy psychologicznej, Instytut Psychologii Zdrowia PTP, Warszawa 1995.

Filipek A., Tożsamość jako istotny element kultury bezpieczeństwa, w: Bezpieczeństwo człowieka a wielokulturowość, red. J. Dębowski, E. Jarmoch, A. W. Świderski, Siedlce 2008.

Gibb J. R., Komunikacja defensywna, w: Mosty zamiast murów. O komunikowaniu się między ludźmi, J. Stewart, Warszawa 2000.

Ginger S., Gestalt. Sztuka kontaktu. Optymistyczne podejście do relacji międzyludzkich, Warszawa 2004.

Grzesiuk L., Psychoterapia. Szkoły, zjawiska, techniki i specyficzne problemy, Warszawa 1995.

Heszen-Niejodek I., Teoria stresu psychologicznego i radzenia sobie, w: Psychologia. Podręcznik akademicki, red. J. Strelau, t. 3, Gdańsk 2007.

Hofstede G., Kultury i organizacje, Warszawa 2000.

Kępiński A., Lęk, Warszawa 1987.

Korporowicz L., Od konfliktu do spotkania kultur, czyli tożsamość jako reguła autotransformacji, w: Komunikacja międzykulturowa. Zbliżenia i impresje, A. Kapciak, L. Korporowicz, A. Tyszka, Warszawa 1995.

Linton R., Dyfuzja, w: Elementy teorii socjologicznych, red. W. Derczyński, A. Jasińska-Kania, J. Szacki, Warszawa 1975.

Ługowska D., Problem tożsamości na tle wybranych koncepcji antropologicznych, w: Bezpieczeństwo człowieka a wielokulturowość, red. J. Dębowski, E. Jarmoch, A. W. Świderski, Siedlce 2008.

Matsumoto D., Juang L., Psychologia międzykulturowa, Gdańsk 2007.

Nowicka E., Świat człowieka - świat kultury, Warszawa 2006.

Obuchowski K., Adaptacja twórcza, Warszawa 1985.

Ociepka B., Komunikowanie międzynarodowe, Wrocław 2002.

Paleczny T., Interpersonalne stosunki międzykulturowe, Kraków 2007.

Pawlik K., Skomunikować się. Rozważania w kontekście filmu Anna i król (reż. Andy Tennant), niepublikowana praca zaliczeniowa w ramach Akademii Artes Liberales 2006.

Spielberger C. D., Theory and research on anxiety, w: Anxiety and Behavior, C. D. Spielberger, Academic Press, New York 1966.

Stephan W. G., Stephan C. W., Wywieranie wptywu przez grupy. Psychologia relacji, Gdańsk 2002.

Stiepanowicz W. A., Szasz S. D., Współdziałanie kultur w warunkach pogranicza. Ujęcie teoretyczne problemu, w: Bezpieczeństwo człowieka a wielokulturowość, red. J. Dębowski, E. Jarmoch, A. W. Świderski, Siedlce 2008.

Szczepaniak P., Strelau J., Wrześniewski K., Diagnoza stylów radzenia sobie ze stresem za pomoca polskiej wersji kwestionariusza CISS Endlera i Parkera, „Przegląd Psychologiczny” 1996, t. 39/1. 
Szewczuk W., Stownik psychologiczny, Warszawa 1979.

Świątkiewicz-Mośny M., Spotkanie z humorem, „Forum akademickie” 2004, nr 3.

Test Inwentarz Stanu i Cechy Lęku STAI, Podręcznik, Pracownia Testów Psychologicznych, Warszawa 1987.

Trzpil A., Wielokulturowość, różnorodność, powierzchowność - szansa czy zagrożenie?, w: Bezpieczeństwo człowieka a wielokulturowość, red. J. Dębowski, E. Jarmoch, A. W. Świderski, Siedlce 2008.

Wallas M., Dialog międzykulturowy - szanse i ograniczenia, w: Drogi i bezdroża komunikacji, red. P. Bering, G. Łukomski, Gniezno 2008.

Wallas M., Poczucie humoru w psychoterapii, „Gestalt” 2000, nr 6.

Wallas M., Znaczenie indywidualnych czynników w procesie akulturacji cudzoziemców. Raport z badań pilotażowych, artykuł oddany do druku 2009.

Welsch W., Transkulturowość. Nowa koncepcja kultury, „Studia kulturoznawcze” 1998, t. 10.

Wrześniewski K., Włodarczyk D., Lęk jako cecha a ocena stresu i stan emocjonalny u osób po zawale serca, w: Lęk, geneza, mechanizmy, funkcje, red. M. Fajkowska, B. Szymura, Warszawa 2009.

\section{Summary}

Multiculturality and peaceful coexistence has recently become a global issue. A foreigner's cultural integration in his/her new country of residence may depend on numerous external and internal factors, yet it requires the individual's personal involvement. The liberal law of the host country will hardly be helpful if the foreigners do not exert their own effort in the course of the acculturation process.

A high level of self-awareness allows them to use the stress of acculturation and its consequences in a way that is advantageous to their own creative development, even if the individuals concerned display anxiety, thus resulting in the self-transformation of an individual's cultural identity. The level of acculturation anxiety produces defined emotional and behavioral outcomes in aliens, while it implies various forms of cultural integration: from its absence, through illusionary integration, passive and active integration, to full integration.

Despite the clash of cultural differences and intensified acculturation stress, setting up a bi-cultural family induces self-transformation and integration with the new culture to a larger extent than in the case of single persons. Owing to the internal change of the value system, a foreigner develops a bi-cultural identity. Bi-cultural relations give their members the sense of belonging to a new cultural group, ensure the development of inter-cultural competence in the form of norms, rules and rituals, which increases the degree of mutual trust, tolerance and the sense of security, thus allowing them to achieve higher acculturation efficiency. 
